\title{
ALFRED LOUIS KROEBER
}

\section{6-1960}

$\mathrm{K}$

ROEBER died in Paris, France, on October

5,1960 at the age of 84 . He had gone to Europe to serve as chairman of a symposium on "Anthropological Horizons" which he had organized for the Wenner-Gren Foundation for Anthropological Research and which was held at Burg-Wartenstein, Austria, September 1825. After the symposium he had gone to Paris for a vacation trip with Mrs. Kroeber. He died suddenly as the result of a heart attack. Kroeber had survived a heart attack 17 years earlier and thereafter, under doctor's orders, had restricted his physical activity as much as the temptations of his professional interests permitted. The trip to Europe in 1960 was a deliberate gamble which he covered by setting his anthropological affairs in order before he left Berkeley.

From about 1939-40, when he was asked to represent American anthropology by writing the key summaries for the presentation volumes for John R. Swanton and A. M. Tozzer, Kroeber was increasingly called upon to serve as spokesman of the field, and he was uniquely qualified for the role by his broad interests and the number and significance of his contributions to all branches of anthropology. His tact, fairness, and sympathetic interest in other people's work made him an ideal prestige chief in a profession of jealous individualists.

Alfred Louis Kroeber was born in Hoboken, New Jersey, on June 11, 1876, the eldest of four children of Florence and Johanna (Mueller) Kroeber. His father had been born in Cologne, Germany, and was brought to the United States by his parents at the age of ten; Alfred's mother was also of German descent, but was born in the United States. Florence Kroeber was in the importing business and was sufficiently well off to keep servants and to have his children educated by tutors and at private schools. The language of the home was German, although both parents were bilingual. Alfred never forgot his German, but in later life spoke it only when doing so would be a courtesy to a German scholar whose English was weak. The religious background of the Kroeber family was Protestant but strongly rationalist, so that religion was not an important influence on the children.
Alfred entered Columbia College in 1892 and majored in English. He took his A.B. in English in 1896 and his M.A. the following year in the same subject, submitting a thesis on the English heroic play. He served as Assistant in English from 1897 to 1899 and was involved in teaching a course on English literature of the 18th century. Meanwhile, however, he had taken courses in anthropology, psychology, history, and philosophy and had become interested in all these subjects. Franz Boas had come to teach anthropology at Columbia in 1896, and Kroeber took his seminar course in North American Indian linguistics out of intellectual curiosity. The following year he had an opportunity to work with six Smith Sound Eskimo informants whom Robert E. Peary had brought to New York. This experience led to his first publications in anthropology, two papers on Eskimo folklore, which appeared in 1899. In the summer of 1899 he went on his first field trip, studying the Arapaho who were living in Oklahoma. This research was done under the auspices of the American Muscum of Natural History on funds supplied by Mrs. Morris K. Jesup. The Arapaho of Oklahoma still retained a considerable amount of their old culture, and Kroeber remembered his work with them as a great emotional experience. In 1900 the American Museum sent him to study the branch of the Arapaho living in Wyoming and a number of neighboring tribes; in 1901 he visited the Gros Ventre and Assiniboine. In the latter year he also submitted a dissertation on the decorative symbolism of the Arapaho and was awarded his Ph.D. in Anthropology. It was the first Ph.D. in this subject awarded by Columbia University and the second in the United States given for a dissertation on an ethnological subject.

Meanwhile, Kroeber began his long connection with California ethnology. In 1900 he accepted an appointment as Curator of Anthropology at the California Academy of Sciences in San Francisco, the plan being that he should undertake a program of ethnographic field work among the Indians of California. His association with the Academy of Sciences was brief, but on the completion of his degree in 1901 he was appointed Instructor in Anthropology 


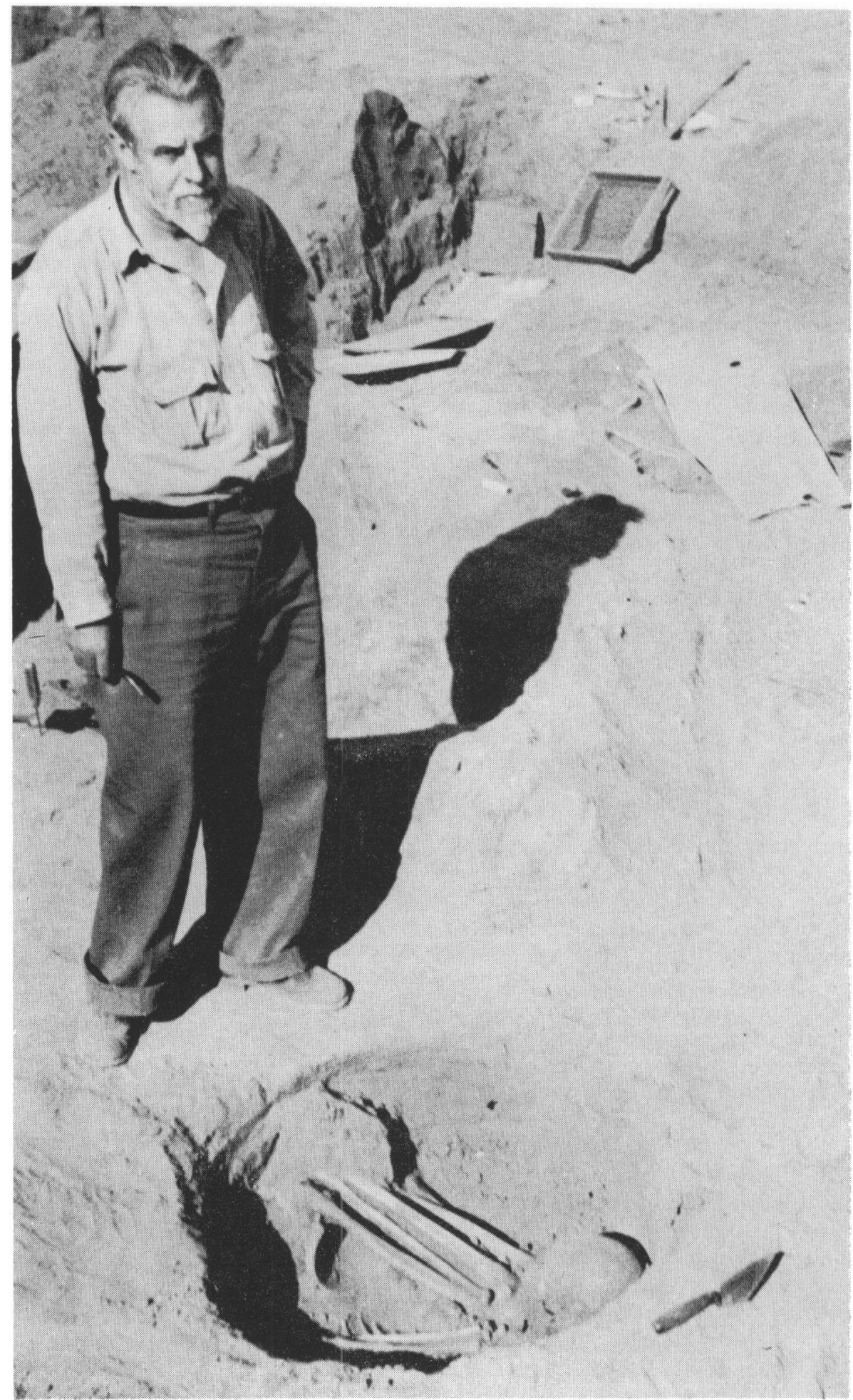

Photo by Robert F. Heizer, July, 1936, Miller Mound, Colusa County, California. 
at the University of California to take part in a broad program of anthropological research at that institution financed by Mrs. Phoebe Apperson Hearst. Again he was assigned the task of doing research on California Indians.

Kroeber's association with the University of California lasted for the rest of his life. He was promoted to the Assistant Professorship in 1906, to the Associate Professorship in 1911, and to the Professorship in 1919. In 1903 Kroeber also became Secretary of the Department of Anthropology and its local Executive Officer, since the Chairman was Professor Frederic Ward Putnam of Harvard University whose other commitments permitted him only brief visits to California. After Putnam's retirement in 1909 Kroeber took full charge of the department administration and maintained this responsibility until 1922, after which he shared it with Robert $\mathrm{H}$. Lowie until his retirement in 1946.

The teaching program of the Department was carried on in Berkeley, but from 1903 to 1931 the collections of the University of California Museum of Anthropology, another department responsibility, were housed in San Francisco. Kroeber was in charge of the $\mathrm{Mu}$ seum also, holding the rank of Curator from 1908 to 1925 and of Director from 1925 to 1946. From 1911 on the Museum maintained an active program of public exhibitions in addition to serving as a center of research.

The Department of Anthropology and the Museum associated with it had both been established at the instance of Mrs. Hearst, who provided all the funds for salaries, facilities, and research until 1906. Kroeber was the first member of the resident staff, the second one with academic rank being Pliny Earle Goddard, who was appointed Instructor in 1902. The original plan was that Kroeber and the other men working for the Department should devote themselves primarily to research until some museum and library resources could be accumulated. Kroeber wanted to teach, however, and offered his first course, which was in North American ethnology, in the spring of 1902. Although there had been no announcement of this course in the catalogue, six students enrolled, including two women. Max Uhle, who had come to Berkeley after two years of archaeological research in Peru under Mrs. Hearst's sponsorship, gave three public lectures on his work in the same semester. Uhle's English was poor, so the lectures had to be given in German, but they were nevertheless well attended. Uhle also wanted to teach and very likely would have offered a full course except for his language handicap. Kroeber offered his course in North American ethnology again in 1903, and Goddard supplemented it by one on California Athabascans. Thereafter, courses were offered every year, but the program was so arranged that each of the instructors lectured only one semester a year until 1908 .

The teaching program was reorganized and expanded in 1903-04, with courses on the Indians of California serving as an introduction to anthropology. A general survey of the field, including physical anthropology, ethnology, and archaeology, was introduced only in 1905-06. The first master's degree in anthropology (M.Sc.) was granted in 1904 to Louisa McDermott, who submitted a thesis on the ethnography and folklore of the Flathead (Salish) of Montana. The first Ph.D. was Samuel A. Barrett in 1908, with a dissertation on Pomo basketry. The Department issued its first publications in 1903.

Kroeber provided the link of continuity through the whole span of the development of anthropology at Berkeley. Others came and went, and the scope and quality of the course offerings varied as the teaching staff changed, grew, or shrank. The low point came in 190809, when Kroeber carried the whole teaching program alone. By the time of the first World War the teaching staff usually consisted of two full-time lecturers plus E. W. Gifford who gave one or two courses a year. Gifford's main responsibilities were in the Museum, of which he became Associate Curator in 1915. An additional teaching position was established in 1927 and still another ten years later. At Kroeber's retirement there were, in effect, four and a half regular teaching positions in the Department of Anthropology.

Kroeber's teaching did not end with his retirement. He served as Visiting Professor at Harvard in 1947-48, and in the same capacity at Columbia from 1948 to 1952 . He taught for one semester each at Brandeis, in 1954, and at Yale, in 1958. His death frustrated a plan for him to give a seminar on the Indians of California at the University of California in 1960 61.

Kroeber was married twice, first to Henriette Rothschild whom he married in 1906. She 
died of tuberculosis in 1913 after a long and difficult illness. In 1926 he married Theodora Kracaw Brown, a widow with two children of her first marriage whom Alfred adopted. He had two children by Theodora, Karl and Ursula. Both his wives shared his intellectual interests, and both published in the field of North American Indian folklore.

The major anthropological organizations of the United States can claim Kroeber's early and loyal support. He was a founding member of the American Anthropological Association and served as its President in 1917. He was also a founding member of the Society for American Archaeology and of the Linguistic Society of America, serving as President of the latter in 1940. He was President of the American Folklore Society in 1906 and Secretary of its California Branch from 1905 to 1908 . He belonged in addition to the American Ethnological Society, the American Antiquarian Society, and the Japan Society of America.

Other memberships reflect recognition of his professional eminence. He was a member of the National Academy of Sciences, a Fellow of the American Academy of Arts and Sciences, a Fellow of the American Association for the Advancement of Science and Vice President of its Section H (Anthropology) in 1906, Vice Chairman of the Division of Anthropology and Psychology of the National Research Council in 1921-22, a Life Member of the California Academy of Sciences and its Curator of Anthropology in 1903-1911 as well as in 1900, a Research Associate of the Chicago Natural History Museum, a Member of the American Philosophical Society, an Honorary Fellow of the Royal Anthropological Institute of Great Britain and Ireland, a Corresponding Member of the Société des Américanistes de Paris, and, before the Russian Revolution, of the Société Impériale des Amis d'Histoire Naturelle of Moscow. He was elected to the National Academy of Science of Peru, and to that of Denmark. He was one of the organizers of the Institute of Andean Research, of New York, in 1937, and was issued its first certificate of membership. He was elected an Honorary Member of the Institute of Andean Studies in Berkeley in 1960.

The Royal Anthropological Institute honored Kroeber with its Huxley Memorial Medal in 1945, and the American Anthropological Association nominated him for the Viking Medal in 1946. He received six honorary degrees, a doctorate from the Universidad Nacional Mayor de San Marcos in Lima in 1942, an Sc.D. from Yale in 1946, an LL.D. from California in 1951, a D.H.L. from Harvard in 1952 and another from Columbia in 1953, and an Sc.D. from Chicago in 1959. On the occasion of his 60th birthday, in 1936, he was honored with a particularly distinguished volume of essays in anthropology, edited by his colleague, Robert H. Lowie. When a local anthropological society was organized in Berkeley in 1949 its members voted to name it the Kroeber Anthropological Society. A building on the Berkeley campus of the University of California, built in 1959 to house the Department and Museum of Anthropology and the Department of Art, was appropriately named Kroeber Hall.

Kroeber's first interests in anthropology, were in linguistics, ethnology, and folklore, and he said on a number of occasions that he considered himself primarily an ethnologist. He also developed a strong interest in archaeology, however, and for a period of 21 years (19221943) a very substantial part of his teaching and research was in this branch of anthropology. In spite of the fact that they formed only part of his total scholarly work, Kroeber's contributions to archaeology are more substantial and important than those of most men who have devoted their entire career to the subject. It is appropriate in this notice for us to concentrate our attention on Kroeber's work in archaeology, leaving his contributions to other fields to be reviewed elsewhere.

Kroeber first became involved in archaeology in 1903 when he took over the position of Secretary and Executive Officer of the Department of Anthropology at the University of California. The Department was still primarily a research organization, carrying out field work in Egypt, Italy, Peru, and California with funds provided by Mrs. Hearst. The Secretary was responsible for the administrative work connected with all the field projects and for receiving, unpacking, and cataloguing the collections resulting from them. Except for the program of ethnological field work in California on which Kroeber himself was working, all of the Department's field projects were archaeological. Kroeber seems to have taken a particular interest in the archaeological work in Peru being done by Max Uhle, whom he got to know during Uhle's stay in San Francisco 
and Berkeley from 1901 to 1903. At any rate, Kroeber's first publication in archaeology was a note in the American Anthropologist in 1904 on Uhle's researches in Peru.

In the spring of 1905 Kroeber offered a course in North American archaeology at the University of California. He gave the course again in the fall of the same year and, for the third and last time, in the fall of 1908. During this same period, from 1905 to 1908 , he served as Secretary of the San Francisco chapter of the Archaeological Institute of America. As far as I have been able to determine, he undertook no archaeological field work of his own at this time, but the Department was carrying on an active program of survey and excavation in California under the direction of the geologist John C. Merriam. Kroeber's chief, Putnam, was particularly interested in this work. There was also a promising student to be trained Nels C. Nelson took his B.L. in 1907 and an M.L. in 1908 with a thesis on the shellmound at Ellis Landing.

The archaeology of North America was still virtually without depth at this time, and it was to be another ten years before the possibility of making chronological distinctions in the archaeological record began to be generally admitted by archaeologists working in the United States. A few pioneers suggested such distinctions earlier, only to have them explained away. It is interesting that Kroeber, who was later to become a pioneer of chronological interpretation himself, was involved in the rejection of one of the soundest earlier efforts in this direction, Max Uhle's claim to have found a record of cultural change in the shellmound at Emeryville on San Francisco Bay, where he dug for Merriam in 1902. Uhle had spent the previous five years sorting out chronological differences in the archaeology of the Peruvian coast, and he had learned to see cultural change in his archaeological data at a time when no one else working in New World archaeology was able to do so.

Uhle's excellent report on his excavations at the Emeryville site was published by the University of California in 1907 (Publications in American Archaeology and Ethnology, Vol. 7, No. 1). Uhle recorded the objects from his excavation by natural levels, of which he distinguished ten in all. He distinguished two phases ("people") in the occupation, the first represented by the lowest levels, VIII to X, and the second by levels I to VII. Speaking of the people of the earlier phase he says: "They may have been neolithic, they may have been connected with the following generation by some common traits, although there is little evidence for this; but the two people certainly differed in cultural characteristics" (p. 40). In his discussion of the age of the mound Uhle pointed out that implements of ground stone were proportionately rarer in the lower levels than in the upper, although they occurred throughout. He mentioned for comparison the European sequence in which a paleolithic stage with only flaked stone tools is followed by a neolithic stage with ground stone tools as well. The passage quoted above, in which he brackets the whole deposit as neolithic, indicates that he did not mean to imply that he had found a paleolithic occupation at Emeryville. He may, however, have felt that he had found a piece of a gradual transition between the two stages of tool manufacture.

Kroeber went over Uhle's notes and collections from Emeryville, and the chronological differences which Uhle claimed seemed to him insignificant. He voiced his doubts, and Nelson made a further excavation at Emeryville in 1906 , at Merriam's request, to collect new evidence. Kroeber remained unconvinced, but Nelson, who was in a sense caught between Kroeber and Uhle, declined to commit himself.

Kroeber's two discussions of the Emeryville problem ("The Archaeology of California," 1909: 15-16; "The History of Native Culture in California," 1923: 140-1) are extremely interesting in retrospect and provide a valuable clue to the thinking behind the general reluctance to admit archaeological evidence of culture change. The 1909 article, being closer to the events, probably reflects the thinking of the time most clearly. In it Kroeber conceded that certain "specialized types," such as charm stones, were found only in the upper levels, while rough stone fragments were commoner in the lower levels. Most kinds of utilitarian tools, including mortars, were found throughout, however, indicating persistence of "the same modes of life." "It does appear that there was some gradual elaboration and refinement of technical processes, but it was a change of degree only, and one in no way to be compared even for a moment with a transition as fundamental as that from palaeolithic to neolithic." In other words, Kroeber at this time visualized cultural change in terms of major 
shifts in technology and subsistence; any changes of less moment were insignificant. $\mathrm{He}$ could not comprehend Uhle's interest in all changes, however minute.

In 1910 Nelson was appointed Instructor in Anthropology and remained in that capacity until 1912. Kroeber turned over the instruction in archaeology to him and devoted his own time to other matters. Some continuing interest in archaeological problems is indicated, however, by the fact that in 1913-14 Kroeber added a course called Anthropology of the Bible ("The Bible as an historical document in the light of archaeology and anthropology"); he gave this course from time to time until 1920-21. In 1914-15 he announced a course called Landmarks of the Past, but it was not actually given and the listing was not repeated. It was during this period, in 1913, that he suggested to Edward W. Gifford the value of experimenting with the measurement of all components of a habitation site. Gifford's work along these lines has been continued in more recent years by S. F. Cook, A. E. Treganza, and Robert F. Heizer, with very valuable results.

In the summer of 1915 Kroeber went to Zuñi pueblo to study kinship and social organization for the American Museum of Natural History. His informants gave him the names of a number of ancient villages nearby, and he indulged his curiosity by visiting some of the sites where they had stood. Differences in the color of the pottery fragments on the surface caught his attention, and he began to collect sherds systematically and work out a seriation of the sites. The obvious color differences gave him a sequence of three phases ("periods"), datable with reference to native traditions and published historical data as present, historic, and prehistoric. Then, by examining the percentages of major decorative techniques in the sample, he suggested subdivisions of the two earlier phases.

Kroeber's seriation of Zuñi sites on the basis of surface collections was not the first successful seriation in North America; A. V. Kidder had published a seriation of the pottery of the Pajarito Plateau the previous year. Kroeber did not read Kidder's report until after his own was written, however, and he appears to have hit on the idea independently. At the same time that Kroeber was working at Zuñi, Nelson, who was also working in the Southwest for the American Museum, was establishing a cultural sequence for the Tano ruins on the basis of stratigraphic analysis. The reports on both of these projects appeared in 1916 . It was the combined work of Kidder, Nelson, and Kroeber which brought about a general realization that archaeological sequences could be established in North America, a realization which, in the next 25 years, led to a complete reorientation of archaeological research in this continent. The revolutionary notion which Kroeber helped to introduce in his report on Zuñi potsherds in 1916 was the one he had rejected in reviewing California archaeology in 1909, the notion that even minor cultural changes are "significant."

Kroeber said later that he was much stimulated by his contact with Zuñi sherds and ruins (The Nature of Culture, 1952: 230). The experience gave him the confidence that he could handle archaeological evidence and brought him the realization that archaeology was a potential source of direct evidence of the past of New World cultures.

The first World War led to a great increase in enrollments in the introductory anthropology course, resulting from a temporary relaxation of the undergraduate course requirements, and for several years Kroeber was too busy trying to cope with a flood of students to undertake any major new project. In 1919, however, he did begin to write reviews of publications dealing with New World archaeology. Some work on archaeology was, of course, included in Kroeber's elementary anthropology course also. In order to provide more suitable reading for beginning students, Kroeber wrote a small book called Three Essays on the Antiquity and Races of Man, which was published by the University of California Press in 1920. It was the nucleus around which his textbook of 1923 was built. One of the essays dealt with human evolution, one with present day races, and one with the prehistoric archaeology of the Old World.

The other pressures on his time eased off after the end of the war, and Kroeber was able to think of undertaking further research in archaeology. In 1922 he began work on the archaeology of Peru.

Kroeber had made up his mind that he wanted to work in either Mexican or Peruvian archaeology, partly because he regarded these, areas as the major sources of cultural influences spreading to the rest of the New World, and partly because the work of Uhle in Peru and 
Boas and Manuel Gamio in Mexico provided some leads to cultural sequence in these areas. In fact, Kroeber worked in both areas, as we shall see, but he chose to make his major commitment to Peru. The University of California had Uhle's superb and well-documented collections from Peru on which he could work conveniently with students, while it had no comparable resources for Mexican archaeology. Kroeber had ascertained by correspondence with Uhle that the excavator did not intend to publish further on his Peruvian collections, so there was no difficulty about prior rights. It was also true that less research was being done in the Peruvian field than in the Mexican, so Kroeber could expect to have it virtually to himself, as, in fact, he did for a number of years.

The Peruvian research program began when William Duncan Strong, who was interested in archaeology, changed his major from zoology to anthropology. Strong needed a job, and Kroeber put him to work classifying and study. ing the Uhle collections from the valley of Chincha. Strong was largely left to his own initiative in this part of the work, but Kroeber would drop in from time to time to see how the project was going and to make suggestions. When the classification was finished, Kroeber took over the results and wrote the report, adding Strong's name to it as co-author.

The Chincha report was issued as the first unit of a systematic review of the Uhle collections from Peru, the purpose of which was to clarify the chronological and spatial relationships of the ancient cultures represented in them. Kroeber's plan was to make an indepent check of Uhle's interpretation of the evidence, accepting at face value only his statements about matters of fact. The extent of Uhle's work in Peru had been such that Kroeber's review amounted in effect to a general review of the chronological problems of Peruvian archaeology.

Kroeber and Strong followed up the Chincha project with a survey of the Uhle pottery collections from Ica, the work being divided in the same way. These two projects were done in 1922-23, which was Strong's senior year, and the reports were issued in 1924. Next, Kroeber worked alone on the collections from Moche, Supe, and Chancay, while Strong analyzed the Ancon collection as a separate project but under Kroeber's supervision. In 1925-26, Anna
H. Gayton, another graduate student, worked with Kroeber on a study of the Nasca collection and did a report on the collection from Nievería as a separate project. This work completed the survey of all major units of the Uhle pottery collections. The reports were published promptly, the last two being issued in 1927.

The procedure which Kroeber and his collaborators followed was to classify the pottery into stylistically defined units and then to discuss the probable chronological order of these units. They established chronological order by an argument from seriation, and the evidence accumulated subsequently suggests that they made very few mistakes in their ordering.

In most cases Kroeber and his students found that the evidence led them to the same interpretations which Uhle had suggested in his letters from the field and in his preliminary publications, but there was an occasional disagreement, and sometimes the Berkeley investigators found that they were able to carry the analysis a step further. Kroeber was very careful to provide a clear explanation of how the evidence was used and how he reached his conclusions. This clarity itself represented an important contribution, making it possible for others to build on the results of Uhle's field work; Uhle's own publications on his field work for the University of California had been too brief to make his evidence available to others. Kroeber's work on the Uhle collections has the same importance for Peruvian archaeology that A. V. Kidder's work has for the archaeology of the Southwestern United States. It formed the basis for all subsequent contributions to the chronology of the area for 20 years, and parts of it have still not been superseded.

There are some important contributions to general archaeological theory in Kroeber's reports on the survey of the Uhle collections. Perhaps the most important is the discussion of the relationship of style and time which appears on pages 229-32 of the Moche report, published in 1925. The distinction between style and time had already been suggested in the Chincha report, and Kroeber used it as the basis for setting up a framework of periods in which to discuss problems of relative chronology. Kroeber's distinction was a fundamental one for archaeology, but at the time he first made it very few other archaeologists were doing so, and none of them had discussed it as a problem. 
The chief weakness of Kroeber's research on the Uhle collections was his practice of classifying pottery without regard to archaeological associations. He would classify a collection by grouping together the pieces which shared the most obvious formal similarities, believing that in this way he was securing units which represented in some sense "natural" units, like species in zoology. Once the units were set up, the relationship of the classificatory units to Uhle's grave associations might be discussed, but the associations were not allowed to disturb the classification itself.

The Ica report contains a striking example of the confusion that can be caused by classifying pottery first and looking at archaeological associations afterwards. In the Ica study Kroeber and Strong missed the archaeological significance of the superposition of poorer burials of the Colonial Period over richer ones dating from the Inca occupation. They missed it because the pottery of the colonial graves is superficially more similar to that of the pre-Inca burials in the same cemetery than it is to the pieces found in the graves of the time of the Inca occupation. Because of the formal similarity they classified the pre-Inca and the colonial pieces together as "Late Ica I," in contrast to a "Late Ica II" unit which included some of the pieces found in the burials of the Inca occupation. The stratification had to be explained away, because it made no sense in terms of the classification. A working belief in the sanctity of types was not a personal peculiarity of Kroeber's. It was general among American archaeologists in the twenties and is still remarkably common.

In the spring semester of 1924 Kroeber interrupted his work on the Uhle collections to undertake a short field trip to the Valley of Mexico. There were some funds available which could be used for such a trip, and recent research in the area had brought to light a variety of remains which invited chronological study. On his arrival in Mexico in March Kroeber consulted Manuel Gamio, who suggested to him the desirability of a stratigraphic exploration in sites assigned to the "Archaic" stage of the valley. Kroeber began his work at San Angel with a series of tests in refuse underlying the Pedregal, a lava flow which is a prominent landmark in the southern part of the valley. These tests were dug in arbitrary levels of $20 \mathrm{~cm}$. in sections $1 \mathrm{~m}$. square. In later cor- respondence Kroeber credited his use of the method of excavation by arbitrary levels to precedent in European practice. His tests at San Angel and others nearby at Copilco, also under the Pedregal, produced no recognizable stratification, but yielded a substantial sample of sherds for comparison. At Copilco he also found the first adobe which anyone working under the Pedregal had recognized.

Following his work under the Pedregal Kroeber visited Teotihuacán at the northeastern side of the valley where he made a cut in the side of one of the tunnels in the Pyramid of the Sun in order to secure a sample of sherds from the fill of the pyramid. He seriated this sample as later than the ones from under the Pedregal. Then he made surface collections at Zacatenco, Ticomán, El Arbolillo, Cerro de la Estrella, and Molina de Moral, and made a cut at Cuicuilco to secure his own sample of sherds from this famous site. By calculating the percentages of nine methods of ornamentation in these collections he seriated them in two intermediate phases between the materials from under the Pedregal and those from the fill of the Pyramid of the Sun. The weakness of this seriation was that it involved treating the collection from each site as a chronological unit, even though the sherds had been collected under such circumstances that Kroeber had no control over the amount of mixing that might have taken place. Nevertheless, the general order proposed was not far different from that suggested later by George C. Vaillant on the basis of much more extensive excavations, and it represents a remarkable tour de force for the time. Kroeber's excavations in the Valley of Mexico were the first ones he had ever undertaken.

A year later, in the spring of 1925 , Kroeber made his first field trip to Peru under the auspices of the Field Museum of Natural History (now the Chicago Natural History Museum). By this time his work on the Uhle collections had progressed far enough so that he had a good knowledge of what Uhle had accomplished, and he was much interested in the problems raised by his predecessor's work. Soon after his arrival in Lima he met Julio C. Tello, who was then in charge of the National Museum of Archaeology. Tello had studied physical anthropology at Harvard, had visited Europe, and had an English wife; he was very helpful to Kroeber, whose Spanish was still 
shaky, and the two men soon became good friends. Tello had strong views on the interpretation of Peruvian archaeology, very different from the ones which Kroeber had developed from his work on Uhle's material, and Kroeber found him a stimulating person to argue with. Kroeber had a far sounder grasp of the use of archaeological evidence than Tello did, and he stuck to his own views in these discussions, but his respect and liking for Tello led him to minimize their disagreements as much as possible. In later years Kroeber was instrumental in securing foreign support for Tello's field work.

Kroeber's first explorations on the 1925 field trip were of necessity conducted in the vicinity of Lima, because unusually heavy rains that year made travel in the provinces virtually impossible. He began by digging some poor burials associated with Interlocking pottery at a small site on the Bajada Balta, in Miraflores, near the house in which he was staying (February 11-12). Then he attempted to dig at the great Huaca Juliana, an Early Intermediate Period mound which was also relatively nearby, but the owners of the surrounding land objected, and Kroeber thought it more prudent not to press his right to work under government authorization. His next try was at the great Inca site of Armatambo, on the slope of the Morro Solar in Chorrillos, but he found the cemetery there badly torn up by pot hunters. Tello then suggested that he try working on the Hacienda Márquez in the Chillón Valley just north of Lima; he did so, and found an intact Late cemetery where he excavated about 80 burials, mostly poor ones, although he got a dozen large decorated mummies.

Kroeber was anxious to find some richer burials to satisfy his Chicago sponsors who wanted some spectacular materials for exhibition, so he shifted his operations in early March to the great mounds of Maranga, lying between Lima and Callao, a site where Uhle had found earlier materials. Here he worked side by side with the Ecuadorian archaeologist Jacinto Jijón y Caamaño, who was also interested in following up Uhle's work. Kroeber made his major excavation in the mound designated Huaca 15, where he had the pleasure of finding a stratification of cemeteries toward the end of March. After excavating 71 poor Late burials he dug through 2 meters of sterile fill to find a group of extended burials associated with Interlocking pottery below. The discovery of this case of stratification gave Kroeber much pleasure at the time, since he was particularly interested in finding stratigraphy. Its actual importance was small, however, for it did nothing but confirm a very obvious seriational argument.

When the rivers fell in April and communications with the provinces were restored Kroeber moved south to the virtually unexplored valley of Cañete and spent several weeks digging at the sites of Cerro Azul and Cerro del Oro, first alone and then jointly with Tello. Each of the Cañete sites yielded a new pottery style, the first datable to Late times and the second to the Middle Horizon. Cañete was the only place Kroeber worked in Peru where Uhle had not preceded him, and in some respects his discoveries at Cañete are the most important results of his Peruvian field work.

In May and June Kroeber made two exploratory trips, one to Trujillo and vicinity, where he visited a number of the more accessible sites and purchased a collection of pottery for the museum in Chicago, and the other to Paracas and Nasca. From Nasca he wrote to D. C. Davies, the Director of the museum, that the area of Nasca was "perhaps the most important in the country," and wished he had a month there.

Looking back on the situation, Kroeber's visit to Paracas has its dramatic aspects. The sites at Paracas, which subsequently yielded some of the most spectacular burials ever found in Peru, were still effectively unknown to archaeologists. W. C. Farabee had been there in 1922 for the University Museum in Philadelphia, but Farabee became an invalid and published nothing on his work. Kroeber rediscovered the place without knowing that Farabee had preceded him. He visited a site at Paracas which is described in his field catalogue as "foot of cerro south of Puntilla," where he collected some fragments of Paracas embroideries ("Nazca style," says his catalogue). This site can only be the one now called Cabeza Larga, at the foot of Cerro Colorado. It is a large habitation site which also contains burials. An old pot hunter described to him the great "cavernas" tombs on the summit of Cerro Colorado; Kroeber misunderstood his informant's directions, however, and thought he was referring to a more distant hill too far away for him to visit in the time available; hence he did not see the "cavernas" himself. He came 
away much impressed by the archaeological possibilities of the area and determined to work there the following year. He said nothing to Tello about his Paracas discoveries. Tello, however, had long been interested in the source of the embroideries which were sold in Pisco and had long intended to explore the neighboring country. At the end of July, after Kroeber had left Peru, Tello went to Pisco with S. K. Lothrop, questioned the pot hunters, and discovered the Paracas sites himself. Tello started digging there at once, and the Paracas cemeteries provided the most dramatic discoveries of his career.

Kroeber went to Peru again in the summer and fall of 1926 for another field trip on behalf of the Field Museum. He took with him his bride of three months and a field assistant, W. Egbert Schenck, who was also accompanied by his wife. Schenck had dug previously in California, but was untrained in Peruvian archaeology and did not know Spanish. The party reached Lima in June; Mrs. Kroeber returned home in late August. The arrangement with the Schencks was not an altogether satisfactory one, and they left the expedition in September. In the latter part of his field work Kroeber was accompanied by his friend Tello.

In July, while waiting for his permit to excavate, Kroeber and his party took the train to the sierra and spent a week in Huancayo visiting nearby sites. One of the places they visited was the sacred spring of Wari-willka which has masonry structures associated with it which are probably of Middle Horizon date. Kroeber was the first archaeologist to see this now famous site. At the end of July, arrangements in Lima being satisfactorily terminated, the party headed south.

Kroeber gave up his plan to dig at Paracas when he heard that Tello had been working there; he resolved to concentrate his efforts in Nasca instead. He did revisit Cabeza Larga on his way to Nasca, however.

The first of the ravines of Nasca is Huayurí, and Kroeber and his party spent a day there before going on to the Nasca valley proper. At Huayuri Kroeber found a pocket of refuse about two and a half meters deep in which he made a test cut "after the European model," segregating the sherds by $50 \mathrm{~cm}$. arbitrary levels. As Kroeber was well aware, this was the first excavation in Peru conducted in refuse purely for the purpose of studying stratification. The refuse at Huayuri was all what Kroeber called "Late Ica," however, and his statistical count of the sherds failed to reveal any differences between levels.

At Nasca Kroeber established a camp in the desert at $\mathrm{La}$ Calera, a short distance south of Nasca town. Here he discovered the now famous desert markings of Nasca. There were several of these markings on the dry plain at La Calera, and Kroeber sketched them from the surrounding hills. His main effort, however, was directed to finding and excavating Nasca burials in the cemeteries along the edges of the valley. The previous year in Berkeley he had been working with Gayton on a seriation of Nasca pottery, and he hoped to check and refine this seriation by securing a large additional sample of Nasca pottery in grave association. He avoided as far as possible getting involved with the later remains in the Nasca valley, and when Schenck found a superposition of Late refuse over Nasca burials at one of the sites where they worked, probably Majoro Chico, Kroeber was little interested in the fact.

Tello spent the month of September visiting Kroeber's camp, and while he was there the two men worked together in the same cemeteries, mainly in the upper part of the valley. They agreed to divide the collections so that grave lots would not be split. After Tello left Kroeber went down to the lower part of the valley and dug at Cahuachi and Estaquería. He was back in Lima by October 19.

Kroeber narrowly missed another major discovery in Nasca. A pot hunter named Carlos Rosas told him about the Middle Horizon site at Pacheco and offered to take him to it. The arrangement fell through, however, and Kroe. ber never went. The next year Tello heard about the Pacheco site from another pot hunter and dug there, finding a spectacular deposit of great ceremonial urns in a distinctive Tiahuanaco-like style. This story was told me by Carlos Rosas. Kroeber never knew how close he came to discovering Pacheco.

Kroeber still had a month left after his return from Nasca, and he devoted it to a survey of the north coast, working in the area between Túcume in the north and Virú in the south. $\mathrm{He}$ did no excavating but concentrated his attention on surface collecting and architectural observations.

Study and publication of the results of the 1925 and 1926 field trips were complicated by 
the fact that Kroeber was in Berkeley while the collections were in Chicago. This situation and Kroeber's manifold other interests brought about delays in publication of the reports, and the report on his most important field project, the excavations at Nasca, was still unfinished at his death. Nevertheless, he did succeed in publishing five monographs on his Peruvian field work, two on the north coast (1926 and 1930), one on Nasca textiles and one on Cañete (both in 1937), and one on early sites in the valley of Lima (1954). He also published two interpretive articles in the American Anthropologist summarizing his conclusions. Kroeber's publications of his Peruvian field work set a new standard of reporting in Peruvian archaeology.

Kroeber did no further field work for the Field Museum, but at one time he intended to do so. In 1928, while Strong was working at the Field Museum, Kroeber negotiated with the Museum administration regarding plans for field work in Peru. He proposed a five-year field program to be carried out under his direction with Strong and other younger people participating. The Museum accepted this plan in principle but had no money to undertake it at the time. Then the depression came along, and plans for more Peruvian research had to be postponed indefinitely.

Early in 1927, soon after Kroeber's return from Peru, Lila M. O'Neale came to him to explore the possibility of taking a doctorate in anthropology. She was a teacher of home economics with a special interest in textile technology. Kroeber encouraged her to work on ancient Peruvian textiles, and she soon became a leader in this specialized but important field. In 1930 she and Kroeber collaborated in a brilliant paper outlining the chronology of Peruvian textiles, and she wrote the technical report on the Nasca textiles he had collected for the Field Museum. This report was published in 1937, as noted above.

Kroeber's course offerings in archaeology followed his research interests with a brief delay. In 1925-26 he offered courses in the Antiquity of Man and in Ancient Civilizations of Mexico and Peru. The former was given only once, while the latter was given in subsequent years until 1929-30. Then Kroeber turned it over to Paul Radin, who taught it only in 1930-31; the following year it was given by Ronald L. Olson, one of Kroeber's former students. Kroeber offered graduate work in Peruvian archaeology for the first time in 1927-28, and the offering was repeated in most years until 1942-43.

Most anthropology students at Berkeley took Kroeber's courses in Peruvian archaeology in the years when they were given, and a few of them went on to make research contributions to the field. The first of Kroeber's students who succeeded in getting to Peru for archaeological research was Ronald Olson, who made a field trip to Nasca and Chachapoyas for the American Museum of Natural History in 1930. Lila O'Neale went on a Guggenheim Fellowship in 1931 and accompanied Tello to Huancayo and Huari. In 1937 Donald Collier dug with Tello in the valley of Casma. Strong went to Peru for the first time in 1940, under the auspices of Columbia University, and Theodore D. McCown explored the Huamachuco area in 1941-42 for the Institute of Andean Research.

In the thirties Kroeber again took an interest in North American archaeology, stimulated by developments which made it seem likely that a synthesis on chronological lines could soon be made for several areas. In 1937 he attempted a preliminary synthesis of California archaeology in a paper published in American Antiquity; it was an attempt to correlate work done by D. B. Rogers and R. L. Olson in the Santa Barbara area, work by E. J. Dawson and W. E. Schenck in the northern San Joaquin valley, the research organized by J. B. Lillard in the lower Sacramento valley, and the earlier work of Uhle and Nelson on the San Francisco Bay shellmounds. This paper provided an important stimulus to the development of a chronological framework for the archaeology of what Kroeber considered his home state.

In 1938-39 Kroeber sensed that enough evidence for chronology in eastern North America had accumulated to make it possible to construct a framework for that area also. He attempted to do so in a graduate seminar on archaeological methods which he gave that year, but the results were disappointing. When, in 1941, James A. Ford and Gordon R. Willey published their synthesis of the archaeology of the eastern United States in the American Anthropologist, Kroeber at once wrote a note of approval and appreciation which appeared in American Antiquity in 1942. He was uniquely qualified to understand the difficulty of what Ford and Willey had accomplished. 
Kroeber returned to Peru for the last time in March and April, 1942, under the auspices of the U. S. Committee on Inter-American Artistic and Intellectual Relations. $\mathrm{He}$ had two months in which to visit sites and collections and confer with archaeologists. It was a strategic time for conversing with archaeologists, for there were four archaeological field parties from the United States operating in Peru that year under the auspices of the Institute of Andean Research, one of them supervised by a student of Kroeber's, T. D. McCown. Kroeber treated the trip as an opportunity for a general review of the state of Peruvian archaeology at the time it was made, and his report, published in 1944, is in some respects his most brilliant archaeological work. It combines descriptive sections on materials about which Kroeber had not previously written with interpretive ones in which chronological and cultural relationships are discussed, and there are penetrating observations and stimulating ideas on almost every page. Working in Peruvian archaeology nearly 20 years later, I still have more frequent cause to consult it than any other single work in the field. The chief weakness of the 1944 report from a theoretical point of view is that in it Kroeber dropped the use of the system of named periods which he has been using in some form since the publication of the Chincha report in 1924. The complete confusion of style, time, and cultural process which soon became general in the Peruvian field underlined the importance of Kroeber's earlier distinction.

Another important landmark resulting from Kroeber's 1942 trip was the lecture on "The methods of Peruvian archaeology" which he delivered at the University of San Marcos in Spanish and which was published in the journal Letras. This article contains Kroeber's only general statement on research methods in archaeology, and it is a statement of extraordinary interest. Kroeber emphasizes the importance of working in small sites of homogeneous culture in order to establish some cultural units before attempting to work out the chronological problems of large and complex sites. Chronologically significant differences can be identified by contrasting the inventories of small homogeneous sites located in the same area, and often the order of the cultural units can be determined at least in some degree by a seriational argument, even if there is no superposition of cultures.
Kroeber's exposition of the principles of seriation of artistic styles is much less sound, for his principles are based on assumptions about stylistic change which have equally plausible alternatives which did not occur to him. Kroeber argues, for example, that straight rays must be earlier than rays with recurved ends, since there has to be a ray with an end before it can be recurved. The alternative which he did not think of is that the recurved ray may begin, not as a straight ray, but as a stemless curl which subsequently develops a stem. This alternative actually occurs in the art of ancient Peru, but no one could have known it in 1942. In the alternative case referred to, the straight ray developed alongside the recurved ray, remaining always about the same length as the stem supporting the curl. In the light of this case it would not be difficult to imagine the possibility of a straight ray developing from a recurved ray.

Kroeber completed his report on the 1942 trip in February, 1943. On September 10 of that year he suffered a heart attack which necessitated several months of complete rest. This crisis led him to think of the future in terms of priorities. There were many others to carry on the archaeological work which he had done so much to stimulate, but he still had a large mass of material remaining from his years of field work in California ethnology which only he could make fully available. He decided that this material should have precedence over his archaeological interests. As he recovered, however, and new discoveries and controversies stimulated him, he found himself constantly being drawn back into archaeology.

In July, 1947, a year after his retirement, Kroeber was invited to attend a general conference on Peruvian archaeology sponsored by the Viking Fund in New York and to write the section of summary and interpretations for the report of the conference. The choice was doubly appropriate, since no one had yet taken Kroeber's place as leader of the Peruvian field, and since several of the participants in the conference had done field work in the Virú Valley in the previous year, following up a line of research which had its beginnings in Kroeber's pioneer reconnaissance of 1926. As usual, Kroeber's comments were sound, stimulating, and contained much of general interest.

In 1949 Jacinto Jijón y Caamaño, who had dug at the mounds of Maranga in 1925 at the 
same time that Kroeber was working there, published a voluminous report on his excavations. The appearance of this report stimulated Kroeber to write up the results of his own work in sites with Interlocking pottery in the Lima valley, the result being his fifth monograph in the Chicago series, issued in 1954.

In 1951 Gordon R. Willey published a detailed review of the problem of Chavin influences in ancient Peruvian cultures. He classified Chavin influence in the art of Paracas as debatable. Kroeber had expressed the belief, in his report on his 1942 trip, that Chavín influence at Paracas was clear and definite. Willey's disagreement reminded Kroeber that he had a collection of unpublished photographs of Paracas specimens in the museum in Lima and inspired him to get these pictures out and use them to review the whole question of Paracas and Chavin relationships. The result was a paper published in 1953 in which he reaffirmed his earlier stand. Subsequent discoveries confirm Kroeber's view of the matter, although the problem is somewhat more complicated than he realized.

In 1952 there was, coincidentally, an unprecedented flurry of activity in Nasca studies. Junius B. Bird, who had been studying Nasca pottery for some years, suggested a new seriation of it which he displayed in a small exhibit at the American Museum of Natural History. W. D. Strong left for Peru under the auspices of Columbia University to conduct fresh excavations in the valleys of Nasca and Ica. I had also been interested in Nasca problems for some time past. I found in Lawrence E. Dawson an able collaborator interested in working on Nasca chronology, and the two of us undertook a restudy of the Nasca style pottery in the Uhle collections at Berkeley. Some of this activity, and perhaps principally Strong's field trip, stimulated Kroeber to take up work again on his own Nasca collections in Chicago. He felt a natural concern lest the publication of new field data reduce the importance of the evidence he had collected in 1926 . He invited Donald Collier, of the staff of the Chicago Natural History Museum and one of his former students, to collaborate with him in preparing a report on his Nasca excavations. Collier undertook to furnish Kroeber with photographs of all the specimens in Chicago and with such notes on them as Kroeber might request.
In the fall of 1952, when he wrote Paracas Cavernas and Chavin, Kroeber was still defending the classification of Nasca pottery which he made with Gayton in 1925-26 (see Paracas Cavernas and Chavin, 1953: 325, note 41), his defense being called forth by the friendly informal criticisms expressed on different grounds by Junius Bird and me. In 1953, however, when Dawson's work with me had advanced to the point where we could propose a new seriation of our own and check it against grave associations, I collected the evidence and made a more systematic attempt to persuade Kroeber that the 1925-26 classification needed so much revision that it would be preferable to start over again with a new one. Kroeber had by then recognized, from working with his own grave lots, that the earlier classification did not fit the archaeological evidence, but he was unwilling to give it up entirely. Instead he prepared a drastic revision which preserves the original labels but alters the categories, bringing them into a rough correspondence with Dawson's results. This revision, which he considered a necessary preliminary to a report on his excavations, was published in 1956.

Kroeber's concern that more recent field work would reduce the importance of his evidence has proved baseless. His Nasca grave associations still provide a unique record, and their publication will be a major contribution to Peruvian archaeology. The Nasca report, which he was writing in collaboration with Donald Collier, was over three-quarters written at the time of his death and already amounted to over 400 pages of manuscript. Collier will complete it according to plans which Kroeber reviewed in a long and detailed letter written to him a few days before Kroeber left for Europe.

In addition to his work on concrete archaeological problems, Kroeber wrote extensively on more abstract questions of theory, especially from 1917 on. A considerable part of his theoretical writing relates to archaeology, although Kroeber himself did not usually think of it in these terms. The impact of his ideas on ethnological theory was perhaps more immediate, but his contributions to the development of a body of theory for archaeology may well turn out to be more significant in the long run.

From his student days Kroeber had a strong interest in diachronic process, in how cultures got to be the way they are. Any inquiry purporting to be diachronic Kroeber called "history," 
and, when it was concerned with customs and institutions, he called it "culture history." His usage of the word "history" is a much looser one than that of professional historians, for whom the term means "diachronic study based on documents." Kroeber never did a piece of historical research in the strict technical sense, although on the one hand he used documents as sources of ethnographic description, in his work on the Indians of California, and on the other hand he made extensive use of secondary historical literature for diachronic purposes. In his own sense, however, his research was persistently "historical."

When Kroeber began research in anthropology at the turn of the century, archaeology was a diachronic study only in parts of Europe and the Near East, although Max Uhle was beginning to suggest some time differences for Peru as well. Elsewhere, and notably in North America where Kroeber expected to work, there was effectively no time depth in archaeology at all. Archaeological research consisted of classifying and describing the monuments, usually with a view to tracing regional differences. This kind of activity naturally had no attractions to someone who was interested in "history" in Kroeber's sense.

On the other hand, Boas had suggested that the "history" of native culture in America could be reconstructed from ethnological data by a process of inference from the distribution of cultural elements, the inferences being based on assumptions about the processes of cultural change. The possibility of achieving some degree of time perspective by such methods was one of the things that attracted Kroeber to ethnology. He recognized that the method might not always give reliable results, but at first and for many years he saw no other hope of tracing the antecedents of native cultures in areas without a documentary record.

In the anthropology of Kroeber's early years, then, ethnology seemed to be the diachronic branch of cultural anthropology, while archaeology was for the most part timeless and purely descriptive, with little to contribute to the study of "culture history." By the time of Kroeber's death, the relationships of archaeology and ethnology to time had been substantially reversed. Archaeology had become overwhelmingly diachronic, while ethnology was becoming timeless, increasingly concerned with the study of synchronic patterns rather than with how cultures got to be the way they are. The diachronic interest of ethnology has largely been restricted to the specialized fields of acculturation and applied anthropology.

Kroeber did not become seriously enough interested in archaeology to do research in it himself until at Zuñi in 1915 he realized that archaeological evidence could be read diachronically. Thereafter, he was one of the leaders of the movement to put time into archaeology and so was in part responsible for the dramatic change which took place in its relationship to ethnology. It is worth noting that he showed no impatience to draw hasty inferences about processes of cultural development before the chronological problems had been solved. The framework of chronology had to be established first. It was a difficult task requiring much hard work and original thought, and Kroeber found it intellectually satisfying.

Kroeber did not regard chronological ordering as an end in itself, however, and as fast as new archaeological evidence became available he drew on it for new diachronic interpretation, at the same time gradually reducing his reliance on reconstruction from distribution. The latter procedure had come under heavy criticism in the thirties, and Kroeber was always sensitive to criticism.

Kroeber also introduced a new and important element into his diachronic studies by his extensive utilization of the secondary historical literature based on documentary sources. His interest in the theoretical possibilities of the documentary record began with the writing of his famous article, "The Superorganic," published in 1917. This article contains a discussion of the theoretical significance of parallel inventions, and the examples are taken from the history of European science and technology from the 17th to the 19th centuries. The theoretical point was an original one of which Kroeber was justly proud (Configurations of Culture Growth, 1944: 12, footnote 2). In 1921-22 he offered a new course called "Outlines of Culture Growth," in which he emphasized the history of invention. This course came to form the core of his undergraduate teaching, and he offered it in most years in which he was in residence until his retirement. In it he developed his concept of stimulus diffusion, on which he published in 1940, and much of the distinctive material that went into 
Configurations of Culture Growth in 1944 and Anthropology in 1948.

As the dates suggest, Kroeber's interest in the historical literature based on documentary sources developed parallel to his interest in diachronic archaeology. As the development of a diachronic archaeological record was a slow business, Kroeber turned to the mass of material already available from documentary sources to see what kinds of patterns might be expected on the basis of a record established on the basis of direct evidence. This inquiry laid the foundation of a body of theory for archaeology.

The importance which this theoretical inquiry attained in Kroeber's conception of the field of anthropology may be seen in his 1948 textbook, about half of which is concerned with problems of cultural process discussed on the basis of archaeological and documentary evidence. The book has, in fact, been severely criticized by anthropologists interested in synchronic generalization because of its emphasis on diachronic problems at the expense of social structure and related matters.

The importance of Kroeber's theoretical contribution should not blind us to the fact that his judgment in matters of theory was not infallible. It was particularly likely to be swayed by his confidence in his ability to make an objective judgment of aesthetic quality and relative excellence. The reader need not agree with Kroeber's conclusions, however, to find his argument stimulating.

Kroeber's work in developing a new kind of theory based on direct evidence for the past was a personal effort, shared only to a limited extent with his graduate students. Although he expounded the ideas that came to him in this field in his courses, he insisted as far as possible that his students do their dissertation research in ethnology. Of 34 doctoral dissertations in anthropology accepted at Berkeley before Kroeber's retirement in 1946 only one, submitted by Waldo R. Wedel in 1936, was on an archaeological subject, and none dealt with the history of invention as recorded in documentary sources or with patterns in the growth of civilization. Kroeber simply refused to permit his students to work on such subjects, although a number of them would have been glad to do so. Whatever advantages this policy of Kroeber's may have had, it certainly did not encourage the graduate students to learn to see theoretical problems in archaeological and documentary evidence. Of course, some learned to do so in other ways.

Personally, Kroeber was extraordinarily kindly and thoughtful of others, patient and tolerant, generous with praise for good work. He had a wide ranging intellectual curiosity and the selfconfidence to follow it into any field of knowledge that attracted his attention. He enjoyed good conversation, spoke easily and informally, and was also a good listener. He was a creative artist with words and ideas, and much of his writing has remarkable literary quality. Parts of the Handbook of the Indians of California, for example, are very close to poetry without thereby being any less effective as scientific reporting.

As a scholar he was a master of inductive generalization, his skill at this difficult art being related to his deep respect for data, particularly the field data which he observed and recorded himself. His respect for data was not, however, reflected in any formal system of field method, either in ethnology or in archaeology. Kroeber's reluctance to give instructions in field method was a legend among his students, and he heartily disapproved of manuals like Notes and Queries in Anthropology. His ideas about archaeological field technique were picked up from reading about excavations in Europe, studying Max Uhle's field catalogues and letters, and watching Tello's assistants find and clear tombs in Peru. He kept no journal in the field, and his notes were extremely sketchy, as he had occasion to realize when he went back to them 30 years later looking for information for further reports. He disliked the mechanics of library research as much as he did those of field work and was not a good bibliographer. He was a meticulous worker, however, and made remarkably few careless errors.

Kroeber's comments on his own work are penetrating and generally sound. He said, for example, "I have a feeling that I write best, as I certainly write most easily, on concrete matters, though their appeal is less" (The Nature of Culture, 1952: 4). His best work, either from an intellectual or a literary point of view, is certainly his work on concrete problems in which his skill at interpreting data finds fullest expression. Many of his most general articles were done on request or to please a general public which was not really interested in research, and he had the good judgment to 
do no more than was necessary to satisfy such demands. No one who knows Kroeber only from his general essays can make an adequate evaluation of his intellectual stature.

Above all, Kroeber had an original mind, and his new ideas stimulated every field to which he turned his attention. It does not matter if, like the rest of us, he was sometimes wrong. By and large, his weaknesses were the weaknesses of his generation, while his strong points were the strong points of the next.

Acknowledgments. In addition to Kroeber's own writings I have drawn on the personal reminiscences of Carl L. Alsberg, published in Essays in Anthropology Presented to A. L. Kroeber, 1936 , pp. xiii-xviii, the annual Announcement of Courses of the University of California for the years 1900-1901 to 1945-46, the letter files of the Department of Anthropology at Berkeley and the Department of Anthropology of the Chicago Natural History Museum, and the records of formal interviews with Kroeber in 1955 in which I asked him to discuss his work in archaeology, and particularly his field work in Peru. I am also very grateful to Robert F. Heizer, Theodore D. McCown, Donald Collier, Jorge C. Muelle, Julian $\mathrm{H}$. Steward, René Millon, James A. Bennyhoff, and A. V. Kidder for suggestions and information. The bibliography is extracted from one which Ann Judith Gibson and I compiled for the Department of Anthropology, University of California, Berkeley. The citations have been modified by the editor in accordance with editorial policy. The complete bibliography is in the American Anthropologist, Volume 63, Number 5, pages 1060-87, 1961.

John Howland Rowe

\section{Archaeological Publications of A. L. Kroeber}

\section{4}

Dr. Uhle's Researches in Peru. American Anthropologist, n.s., Vol. 6, No. 4, pp. 576-7. Lancaster.

\section{5}

The Department of Anthropology of the Uniqersity of California. (With Frederic Ward Putnam.) University of California Publications. The Press, Berkeley. $38 \mathrm{pp}$.

\section{6}

Dr. Max Uhle. American Anthropologist, n.s., Vol. 8, No. 1, p. 202. Lancaster.

Guide to the Collections of the Department of Anthropology, University of California. University of California Publications. The Press, Berkeley. $15 \mathrm{pp}$.

Recent Progress in American Anthropology. University of California. American Anthropologist, n.s., Vol. 8 , No. 3, pp. 483-92. Lancaster. [Reprints titled: Progress in Anthropology at the University of California.]

Recent Researches by the University of California. American Anthropologist, n.s., Vol. 8, No. 3, p. 606. Lancaster.

\section{9}

The Archaeology of California. Putnam Anniversary Volume. Anthropological Essays Presented to Frederic Ward Putnam in Honor of his Seventieth
Birthday, April 16, 1909, by his Friends and Associates, pp. 1-42. G. E. Stechert, New York.

1910

At the Bedrock of History. Sunset, Vol. 25, No. 3, pp. 255-60. San Francisco.

1911

Shellmounds at San Francisco and San Mateo. Records of the Past, Vol. 10, Part 4, pp. 227-8. Washington.

1916

Zuñi Culture Sequences. Proceedings of the National Academy of Sciences, Vol. 2, No. 1, pp. 42-5. Baltimore.

Zuñi Potsherds. Anthropological Papers of the American Museum of Natural History, Vol. 18, Part 1, pp. [iii], 1-37. New York.

\section{7}

The Superorganic. American Anthropologist, Vol. 19, No. 2, pp. 163-213. Lancaster.

Review: Prolegomena to History. Frederick J. Teggart. (University of California Publications in History, Vol. 4, No. 3, Berkeley, 1916.) American Anthropologist, Vol. 19, No. 1, pp. 68-70. Lancaster.

\section{9}

On the Principle of Order in Civilization as Exemplified by Changes of Fashion. American Anthropologist. Vol. 21, No. 3, pp. 235-63. Lancaster.

Review: The Aztec Ruin. Earl H. Morris. (Anthropological Papers of the American Museum of Natural History, Vol. 26, Pt. 1, 1919.) American Anthropologist, Vol. 21, No. 2, p. 194. Lancaster.

1920

Guide to Selected Objects of Unusual Interest. University of California Museum of Anthropology, The Hearst Collections at Second and Parnassus Avenues, San Francisco. University of California Press, Berkeley. 14 pp.

Three Essays on the Antiquity and Races of Man. University of California Syllabus Series No. 119. University of California Press, Berkeley. 80 pp.

Review: Certain Aboriginal Pottery from Southern California. George G. Heye. (Indian Notes and Monographs, Vol. 7, No. 1, Museum of the American Indian, Heye Foundation, New York, 1919.) American Anthropologist, Vol. 22, No. 2, pp. 186-88. Lancaster.

Review: Preliminary Account of the Antiquities of the Region between the Mancos and La Plata Rivers in Southwestern Colorado. Earl H. Morris. (Thirtythird Annual Report of the Bureau of American Ethnology, pp. 155-206, Washington, 1919.) American Anthropologist, Vol. 22, No. 4, pp. 383-4. Lancaster.

\section{1}

Review: A History of the Art of Writing. William A. Mason. (Macmillan, New York, 1920.) American Anthropologist, Vol. 23, No. 4, pp. 478-9. Lancaster.

Review: New York City in Indian Possession. Reginald Pelham Bolton. (Indian Notes and Monographs, Vol. 2, No. 7, Museum of the American Indian, Heye Foundation, New York, 1920.) American Anthropologist, Vol. 23, No. 3, p. 363. Lancaster.

1922

Review: The Copper and Bronze Ages in South America. Erland Nordenskiöld. (Comparative Ethnographical 
Studies 4, Göteborg, 1921.) American Anthropologist, Vol. 24, No. 4, pp. 469-70. Menasha.

\section{3}

Anthropology. Harcourt, Brace, New York. x, 523 pp.

Historical Introduction. Phoebe Apperson Hearst Memorial Volume. University of California Publications in American Archaeology and Ethnology, Vol. 20, pp. ix-xiv. Berkeley.

The History of Native Culture in California. University of California Publications in American Archaeology and Ethnology, Vol. 20, pp. 125-42. Berkeley.

Review: Social Change: with Respect to Culture and Original Nature. William Fielding Ogburn. (Huebsch, New York, 1922.) American Anthropologist, Vol. 25, No. 2, pp. 265-66. Menasha.

\section{4}

Explorations at Chincha, by Max Uhle, edited by A. L. Kroeber. University of California Publications in American Archaeology and Ethnology, Vol. 21, No. 2, pp. 55-94. Berkeley.

The Uhle Collections from Chincha. (With William Duncan Strong.) University of California Publications in American Archaeology and Ethnology, Vol. 21, No. 1, pp. [i-ii], 1-54. Berkeley.

The Uhle Pottery Collections from Ica. (With William Duncan Strong.) With Three Appendices by Max Uhle. University of California Publications in American Archaeology and Ethnology, Vol. 21, No. 3, pp. [i-ii], 95-133. Berkeley.

Review: Los principios de la civilización en la sierra peruana. Orígenes centroamericanos. Influencias mayas en el alto Ecuador. Los principios de las antiguas civilizaciones peruanas. Fundamentos étnicos y arqueología de Arica y Tacna. Civilizaciones mayoides de la costa pacífica de Sudamérica. Max Uhle. (Series of articles in various issues of Boletín de la Academia Nacional de Historia de Ecuador, 192023.) American Anthropologist, Vol. 26, No. 1, pp. 100-102. Menasha.

\section{5}

Archaic Culture Horizons in the Valley of Mexico. University of California Publications in American Archaeology and Ethnology, Vol. 17, No. 7, pp. [i-ii], 373-408. Berkeley.

Handbook of the Indians of California. Bureau of American Ethnology, Bulletin 78. Washington. xviii, 995 pp.

The Uhle Pottery Collections from Moche. University of California Publications in American Archaeology and Ethnology, Vol. 21, No. 5, pp. [i-ii], 191-234. Berkeley.

The Uhle Pottery Collections from Supe. University of California Publications in American Archaeology and Ethnology, Vol. 21, No. 6, pp. [i-ii], 235-64. Berkeley.

Archaeological Explorations in Peru. Part I, Ancient Pottery from Trujillo. Field Museum of Natural History, Anthropology Memoirs, Vol. 2, No. 1, pp. 144. Chicago.

Culture Stratifications in Peru. American Anthropologist, Vol. 28, No. 2, pp. 331-51. Menasha.

The Uhle Pottery Collections from Chancay. With Appendix by Max Uhle. University of California Publications in American Archaeology and Ethnology, Vol. 21, No. 7, pp. [i-ii], 265-304. Berkeley.
1927

Coast and Highland in Prehistoric Peru. American Anthropologist, Vol. 29, No. 4, pp. 625-53. Menasha.

Disposal of the Dead. American Anthropologist, Vol. 29, No. 3, pp. 308-15. Menasha.

The Superorganic. The Sociological Press, Hanover, Minneapolis, Liverpool. 37 pp. [Reprinted, with revisions, from the American Anthropologist, Vol. 19, No. 2, 1917.]

The Uhle Pottery Collections from Nazca. (With Anna Hadwick Gayton.) University of California Publications in American Archaeology and Ethnology, Vol. 24, No. 1, pp. [i-ii], 1-46. Berkeley.

Review: The Technique of South American Ceramics. S. Linné. (Göteborg, 1925.) American Anthropologist, Vol. 29, No. 3, p. 354. Menasha.

\section{8}

Review: Prehistoric India, Its Place in the World's Cul ture, second edition. Panchanan Mitra. (University of Calcutta, 1927.) American Anthropologist, Vol. 30, No. 1, pp. 140-1. Menasha.

Review: Tribes and Temples. Frans Blom and Oliver La Farge, two volumes. (Tulane University, New Orleans, 1926.) American Anthropologist, Vol. 30, No. 1, pp. 133-5. Menasha.

\section{9}

Archaeological Field Work in North America during 1928. California. American Anthropologist, Vol. 31, No. 2, pp. 340-1. Menasha.

Preface. Lovelock Cave, by L. L. Loud and M. R. Harrington. University of California Publications in American Archaeology and Ethnology, Vol. 25, No. 1, pp. vii-viii. Berkeley.

Review: Primitive Art. Franz Boas. (Institute for Comparative Culture Research, Oslo, 1927; Harvard University Press.) American Anthropologist, Vol. 31, No. 1, pp. 138-40. Menasha.

Review: Southwest Museum Papers. Number One: An Anthropological Reconnaissance in Sonora. Monroe Amsden. Number Two: Excavations at Casa Grande, Arizona. Harold S. Gladwin. (Southwest Museum, Los Angeles, 1928.) American Anthropologist, Vol. 31, No. 3, pp. 513-6. Menasha.

Review: Ueber die Wurzeln der Tainischen Kultur. Teil I, Materielle Kultur. Sven Lovén. (Göteborg, 1924.) American Anthropologist, n.s., Vol. 31, No. 3, p. 517. Menasha.

\section{0}

Archaeological Explorations in Peru. Part II, The Northern Coast. Field Museum of Natural History, Anthropology, Memoirs, Vol. 2, No. 2, pp. 45-116. Chicago.

Archaeology. Encyclopaedia of the Social Sciences, Vol. 2, pp. 163-7. Macmillan, New York.

Art, Primitive. Encyclopaedia of the Social Sciences, Vol. 2, pp. 226-9. Macmillan, New York.

Cultural Relations between North and South America. Proceedings of the Twenty-third International Congress of Americanists, Held at New York, September 17-22, 1928, pp. 5-22. New York.

Textile Periods in Ancient Peru. (With Lila Morris O'Neale.) University of California Publications in American Archaeology and Ethnology, Vol. 28, No. 2, pp. [i-iv], 23-56. Berkeley.

Review: L'Amérique pré-colombienne et la conquête européene [sic]. Louis Pierre Langlois. (Boccard, Paris, 1928.) American Anthropologist, Vol. 32, No. 4, pp. 690-1. Menasha. 
Review: Dress and Ornaments in Ancient Peru: Archaeological and Historic Studies. Gösta Montell. (Göteborg, 1929; Oxford University Press.) American Anthropologist, Vol. 32, No. 3, pp. 551-2. Menasha.

Revieq: Handbuch der präkolumbischen Kulturen in Lateinamerika. Th. W. Danzel. (Hanseatische Verlagsanstalt, Hamburg, 1927. . . .) American Anthropologist, Vol. 32, No. 4, p. 691. Menasha.

Review: Monumentale vorgeschichtliche Kunst: Ausgrabungen im Quellgebiet des Magdalena in Kolumbien und ihre Ausstrahlungen in Amerika. K. Th. Preuss. (Vandenhoeck und Rupprecht, Göttingen, 1929.) American Anthropologist, Vol. 32, No. 4, pp. 691-2. Menasha.

Review: Our Prehistoric Ancestors. Herdman Fitzgerald Cleland. (Coward-McCann, New York, 1928.) American Anthropologist, Vol. 32, No. 2, p. 305. Menasha.

Review: Tizoc, Great Lord of the Aztecs, 1481-1486. Marshall H. Saville. (Contributions from the $\mathrm{Mu}$. seum of the American Indian, Heye Foundation, Vol. 7, No. 4, 1929.) American Anthropologist, Vol. 32, No. 3, p. 549. Menasha.

1931

Review: Bulletin of the Texas Archaeological and Palaeontological Society, Volume 2. (Abilene, 1930.) American Anthropologist, Vol. 33, No. 2, p. 238. Menasha.

Review: Darien in the Past. S. Linné. (Göteborgs Kungl. Vetenskaps och Vitterhets-Samhälles Handlingar, 5 följden, Ser. A, Vol. 1, No. 3, 1929.) American Anthropologist, Vol. 33, No. 1, pp. 118-9. Menasha.

Review: Peruvian Textiles: Examples of the Pre-Incaic Period. With a Chronology of Early Peruvian Cultures by Philip Ainsworth Means, and an Introduction by Joseph Breck. (Metropolitan Museum of Art, New York, 1930.) American Anthropologist, Vol. 33, No. 2, p. 244. Menasha.

\section{2}

Review: Machu Picchu: A Citadel of the Incas. Hiram Bingham. (Yale University Press for the National Geographic Society, 1930.) American Anthropologist, Vol. 34, No. 1, pp. 152-3. Menasha.

\section{3}

Anthropology. With Supplement. Harcourt, Brace, New York. x, 524 pp. A Supplement, 1923-1933, 32 pp., bound at end.

Anthropology 103A. Culture Growth. Professor Kroeber. University of California Press, Syllabus FQ. August. Berkeley. 11 pp., mimeographed.

A Supplement to Anthropology, by A. L. Kroeber, 19231933. Harcourt, Brace, New York. 32 pp.

Review: Archaeological Atlas of Michigan. Wilbert B. Hinsdale. (Michigan Handbook Series, No. 4, University of Michigan; Ann Arbor, 1931.) Distribution of the Aboriginal Population of Michigan. W. B. Hinsdale. (Occasional Contributions from the $\mathrm{Mu}$ seum of Anthropology of the University of Michigan, No. 2, 1932.) American Anthropologist, Vol. 35, No. 1, pp. 180-1. Menasha.

\section{4}

Anthropology 103B. Culture Growth. University of California Press, Syllabus FX. January. Berkeley. 12 pp., mimeographed.

\section{5}

History and Science in Anthropology. American Anthropologist, Vol. 37, No. 4, pp. 539-69. Menasha.
Preface. Culture Element Distributions: I, The Structure of California Indian Culture, by Stanislaw Klimek. University of California Publications in American Archaeology and Ethnology, Vol. 37, No. 1, pp. 1-11. Berkeley.

$$
1936
$$

Prospects in California Prehistory. American Antiquity, Vol. 2, No. 2, pp. 108-16. Menasha.

\section{7}

Archaeological Explorations in Peru. Part IV, Cañete Valley. Field Museum of Natural History, Anthropology, Memoirs, Vol. 2, No. 4, pp. 219-73. Chicago.

Preface. Archaeological Explorations in Peru. Part III, Textiles of the Early Nazca Period, by Lila Morris O'Neale. Field Museum of Natural History, Anthropology, Memoirs, Vol. 2, No. 3, pp. 127-9. Chicago.

Review: The Archaeology of the Deer Creek-Cosumnes Area, Sacramento Co., California. J. B. Lillard and W. K. Purves. (Bulletin, Sacramento Junior College, 1, 1936.) American Anthropologist, Vol. 39, No. 1, p. 144. Menasha.

\section{8}

Anthropology 103A. Culture Growth. Professor Kroeber. University of California Syllabus Series, Syllabus KL. August. University of California Press, Berkeley. 12 pp., mimeographed.

Lodi Man. Science, n.s., Vol. 87, No. 2250, pp. 137-8. New York.

1939

Anthropology 103B. Culture Growth, Part II. University of California Syllabus Series, Syllabus KW. January. University of California Press, Berkeley. 11 pp., mimeographed.

Cultural and Natural Areas of Native North America. University of California Publications in American Archaeology and Ethnology, Vol. 38. Berkeley. xii, $242 \mathrm{pp}$. [Also issued in hard covers as a separate book.]

South America. Pacific Cultures; Official Catalog, Department of Fine Arts, Division of Pacific Cultures, pp. 133-45. Golden Gate International Exposition, San Francisco.

Sudamérica; Perú. Revista del Museo Nacional, Tomo 8, No. 2, II Semestre, pp. 320-5. Lima. [A translation by J. Eugenio Garro of pp. 133-6 of the previous item].

\section{0}

Conclusions: the Present Status of Americanistic Problems. The Maya and Their Neighbors [essays in honor of Alfred Marston Tozzer, edited by Clarence, L. Hay and others], pp. 460-89. D. Appleton-Century, New York.

Indians of Peru. Aboriginal Cultures of the Western Hemisphere, Golden Gate International Exposition, 1940, Treasure Island, San Francisco, pp. 25-32. U.S. Golden Gate International Exposition Commission, San Francisco.

Statistical Classification. American Antiquity, Vol. 6, No. 1, pp. 29-44. Menasha.

Stimulus Diffusion. American Anthropologist, Vol. 42, No. 1, pp. 1-20. Menasha.

Three Centuries of Women's Dress Fashions; a Quantitative Analysis. (With Jane Richardson.) Anthropological Records, Vol. 5, No. 2, pp. i-iv, 111-53. Berkeley.

Review: Archaeology of the North Coast of Peru: an Account of Exploration and Excavation in Viru and 
Lambayeque Valleys. Wendell C. Bennett. (Anthropological Papers, American Museum of Natural History, Vol. 37, Part 1, pp. 1-153, New York, 1939.) American Anthropologist, Vol. 42, No. 3, pp. 508-10. Menasha.

1941

Anthropology 127. Primitive Art. Professor Kroeber. University of California Syllabus Series, Syllabus NH. August. University of California Press, Berkeley and Los Angeles. 12 pp., mimeographed.

Culture Element Distributions: XV, Salt, Dogs, Tobacco. Anthropological Records, Vol. 6, No. 1, pp. [i-ii], 1-20. Berkeley and Los Angeles.

\section{2}

Anthropological Research in Ibero-America and AngloAmerica. Vigesimoséptimo Congreso Internacional de Americanistas, Actas de la Primera Sesión, celebrada en la ciudad de Mexico en 1939, Tomo I, pp. 81-91. México.

Anthropology 103A-103B. Culture Growth. Professor Kroeber. University of California Syllabus Series, Syllabus OE. October. University of California Press, Berkeley and Los Angeles. 30 pp., mimeographed.

Cerámica paleteada de Lambayeque. (With Jorge Clemente Muelle.) Revista del Museo Nacional, Vol. 11, No. 1, I Semestre, pp. 1-24. Lima.

Introduction. Archaeological Evidence of Sebastian Rodriguez Cermeño's California Visit in 1595, by Robert Fleming Heizer, pp. 1-3. California Historical Society, San Francisco.

Los métodos de la arqueología peruana. Letras; órgano de la Facultad de Letras y Pedagogía, Universidad Nacional Mayor de San Marcos, No. 22, segundo cuatrimestre, pp. 205-26. Lima.

On "An Interpretation of the Prehistory of the Eastern United States." American Antiquity, Vol. 7, No. 3, p. 326. Menasha.

Tapajó Pottery. American Antiquity, Vol. 7, No. 4, pp. 403-5. Menasha.

\section{3}

Review: A Study of History. Arnold J. Toynbee. (Vols. 1-6. London, 1934-39.) American Anthropologist, Vol. 45, No. 2, pp. 294-9. Menasha.

\section{4}

Configurations of Culture Growth. The University of California Press, Berkeley and Los Angeles. x, 882 pp.

Peruvian Archeology in 1942. Viking Fund Publications in Anthropology, No. 4. New York. $151 \mathrm{pp}$.

Review: Archeological Studies in Peru, 1941-1942. William Duncan Strong, Gordon R. Willey, and John M. Corbett. (Columbia Studies in Archeology and Ethnology, Vol. 1, Columbia University Press, 1943.) American Anthropologist, Vol. 46, No. 2, pp. 250-1. Menasha.

Review: The Problem of the Antiquity of Man in Australia. D. J. Mahony. The Keilor Fossil Skull: Anatomical Description. J. Wunderly. The Keilor Fossil Skull: Palate and Upper Dental Arch. William Adam. The Keilor Fossil Skull: Geological Evidence of Antiquity. D. J. Mahony. (Mem. Nat. Mus. Melbourne No. 13, 1943, pp. 7-81.) American Journal of Physical Anthropology, n.s:, Vol. 2, No. 3, pp. 319-21. Philadelphia.

1945

Antropología general. Primera edición española, corregida por el autor. Versión española de Javier Romero. Fondo de Cultura Económica, Mexico. 527 pp.
Review: The North Highlands of Peru: Excavations in the Callejón de Huaylas and at Chavín de Huantar. Wendell C. Bennett. (Anthropological Papers of the American Museum of Natural History, Vol. 39, Part 1, pp. 1-114, New York, 1944.) American Antiquity, Vol. 10, No. 3, pp. 314-315. Menasha.

Review: Vistas arqueológicas del noroeste del Perú. $H$. Horkheimer. (Instituto Arqueológico de la Universidad Nacional de Trujillo, Trujillo, 1944.) American Antiquity, Vol. 11, No. 2, pp. 125-6. Menasha.

\section{6}

The Ancient Orkoumenê as an Historic Culture Aggregate. Huxley Memorial Lecture for 1945. The Royal Anthropological Institute of Great Britain and Ireland, London. $12 \mathrm{pp}$.

The Chibcha. Handbook of South American Indians, Bureau of American Ethnology, Bulletin 143, Vol. 2, pp. 887-909. Washington.

History and Evolution. Southwestern Journal of Anthropology, Vol. 2, No. 1, pp. 1-15. Albuquerque.

The Range of the American Anthropologist. American Anthropologist, Vol. 48, No. 2, pp. 297-9. Menasha.

University of California Museum of Anthropology. Report to President Robert Gordon Sproul for the Year Ending June 30, 1946. (With Edward Winslow Gifford.) [University of California Press, Berkeley]. $18 \mathrm{pp}$.

Review: Cultura Salinar: sintesis monográfica. Rafael Larco Hoyle. (Chiclín, Trujillo, 1944.) American Antiquity, Vol. 12, No. 2, p. 131. Menasha.

\section{7}

Culture Groupings in Asia. Southwestern Journal of Anthropology, Vol. 3, No. 4, pp. 322-30. Albuquerque.

Obituary: L. L. Loud. American Antiquity, Vol. 12, No. 3, p. 180. Menasha.

Review: The Ancient Maya. Sylvanus Griswold Morley. (Stanford University Press, Stanford, 1946.) Pacific Historical Review, Vol. 16, No. 2, pp. 181-3. Berkeley and Los Angeles.

Review: The Commonwealth of Art: Style in the Fine Arts, Music and the Dance. Curt Sachs. (W. W. Norton, New York, 1946.) American Anthropologist, Vol. 49, No. 3, pp. 485-7. Menasha.

\section{8}

Anthropology; Race, Language, Culture, Psychology, Prehistory, new edition, revised. Harcourt, Brace, New York. xii, 856, xxxix pp.

Art Styles in Prehistoric Peru. Some Educational and Anthropological Aspects of Latin America. University of Texas, Institute of Latin American Studies, Latin American. Studies, 5, pp. 56-79. Austin.

Summary and Interpretations. A Reappraisal of Peruvian Archaeology, assembled by Wendell C. Bennett. Memoirs of the Society for American Archaeology, No. 4, pp. 113-21. Menasha.

Reqiew: Archéologie de la province d'Esmeraldas, Equateur. Raoul d'Harcourt. (Journal de la Société des Américanistes, n.s., Vol. 35 , pp. $61-200$, pls. 1-61, Paris, 1942 [1947].) American Antiquity, Vol. 14, No. 2, pp. 139-40. Menasha.

\section{9}

The Ancient Oikoumenê as an Historic Culture Aggregate. Huxley Memorial Lecture for 1945. The Journal of the Royal Anthropological Institute of Great Britain and Ireland, Vol. 75, Parts 1, 2, 1945, pp. 920. London. 
La arqueología peruana en 1942. Traducción del inglés de los primeros capítulos del libro de igual título, hecha por el Dr. Manuel G. Suárez Polar, catedrático del curso de Arqueología. Revista, órgano de la Universidad Nacional de San Agustin de Arequipa, Año 21, No. 29, primer semestre de 1949, pp. 48-66. Arequipa.

Art. Handbook of South American Indians, Bureau of American Ethnology, Bulletin 143, Vol. 5, pp. 411-92. Washington.

Obituary: Lila Morris O'Neale, 1886-1948. (With Lea Van P. Miller, Barbara Armstrong, and Hope M. Gladding.) University of California, In Memoriam, 1948. [University of California Press, Berkeley.] Title, 5 pp.

\section{0}

Anthropology. Scientific American, Vol. 183, No. 3, pp. 87-94. New York.

Have Civilizations a Life History? Centennial, A.A.A.S. Collected Papers Presented at the Centennial Celebration, Washington, D.C., September 13-17, 1948, pp. 9-13. American Association for the Advancement of Science, Washington.

A Local Style of Lifelike Sculptured Stone Heads in Ancient Peru. Beiträge zur Gesellungs- und Völkerwissenschaft; Festschrift zum achtzigsten Geburtstag von Professor Richard Thurnwald, pp. 195-8. Verlag Gebr. Mann, Berlin.

Review: Metaphysik des Untergangs: eine Kulturkritische Studie über Oswald Spengler. Manfred Schröter. (Leibniz Verlag, Munich, 1949.) American Anthropologist, Vol. 52, No. 1, pp. 102-3. Menasha.

\section{1}

At the Bedrock of History. Papers on California Archaeology: 10-12; Reports of the University of California Archaeological Survey, No. 11, May, pp. 5-10. Berkeley.

Configurations, Causes and St. Augustine. American Anthropologist, Vol. 53, No. 2, pp. 279-83. Menasha.

Great Art Styles of Ancient South America. The Civilizations of Ancient America, Selected Papers of the XXIXth International Congress of Americanists, edited by Sol Tax, pp. 207-15. University of Chicago Press, Chicago.

Is Western Civilization Disintegrating or Reconstituting? Proceedings of the American Philosophical Society, Vol. 95, No. 2, pp. 100-04. Philadelphia.

The Viking Fund and Anthropology. The First Ten Years, 1941-1951, including a Report on the Fund's Activities for the Year Ending January 31, 1951, pp. 4-12. Viking Fund, New York.

Review: The Alphabet: A Key to the History of Mankind. David Diringer. (Philosophical Library, New York, 1948.) American Anthropologist, Vol. 53, No. 2, pp. 258-9. Menasha.

Review: China: a Short Cultural History. C. P. Fitzgerald. (Frederick A. Praeger, New York, 1950.) American Anthropologist, Vol. 53, No. 3, pp. 402-3. Menasha.

The Nature of Culture. University of Chicago Press, Chicago. x, $438 \mathrm{pp}$.

The Delimitation of Civilizations. Journal of the History of Ideas, Vol. 14, No. 2, pp. 264-75. Lancaster and New York.
Handbook of the Indians of California. California Book Company, Berkeley. [4], xviii, 995 pp. [Photolithographic facsimile with an additional foreword by the author, p. iii.]

Paracas Cavernas and Chavín. University of California Publications in American Archaeology and Ethnology, Vol. 40, No. 8, pp. [i-iv], 313-48. Berkeley and Los Angeles.

Review: A Study of Classic Maya Sculpture. Tatiana Proskouriakoff. (Carnegie Institution of Washington, Publication 593, Washington, 1950.) Journal of American Folklore, Vol. 66, No. 260, pp. 181-3. Richmond.

\section{4}

Comment [on Gatherers and Farmers in the Greater Southwest: a Problem in Classification, by Paul Kirchhoff.] American Anthropologist, Vol. 56, No. 4, pp. 556-9. Menasha.

Obituary: John Linton Myres: 1869-1954. Man, Vol. 54, Article 48, p. 38. London.

Letter from Kroeber to Uhle, March 6, 1903. Max Uhle, 1856-1944; a Memoir of the Father of Peruvian Archaeology, by John Howland Rowe. University of California Publications in American Archaeology and Ethnology, Vol. 46, No. 1, p. 109. Berkeley and Los Angeles.

Paracas Cavernas and Chavín. Letras, Universidad Nacional Mayor de San Marcos, No. 49, primer semestre, 1953, pp. 49-71. Lima.

The Place of Anthropology in Universities. American Anthropologist, Vol. 56, No. 5, pp. 764-67. Menasha.

Proto-Lima; a Middle Period Culture of Peru. With Appendix on Cloths, by Dwight T. Wallace. Chicago Natural History Museum, Fieldiana: Anthropology, Vol. 44, No. 1, pp. [i-ii], 1-157. Chicago.

Quantitative Analyses of Ancient Peruvian Metal. American Antiquity, Vol. 20, No. 2, pp. 160-2. Salt Lake City.

\section{5}

Proto-Lima; un período cultural intermedio del Perú. Síntesis e interpretación. (Translated by Pedro Rojas Ponce.) Revista del Museo Nacional de Antropología y Arqueología, Vol. 2, No. 2, primer semestre, pp. 141-5. Lima.

\section{6}

Las colecciones cerámicas de Uhle de la región de Ica por Kroeber y Strong. (Translated by Ernesto Tabio.) Revista del Museo Regional de Ica, Año 7, No. 8, pp. 10-38. Ica.

Foreword. Feudalism in History, edited by Rushton Coulborn, pp. vii-ix. Princeton University Press, Princeton.

Toward Definition of the Nazca Style. University of California Publications in American Archaeology and Ethnology, Vol. 43, No. 4, pp. i-iv, 327-432. Berkeley and Los Angeles.

\section{7}

An Anthropologist Looks at History. Pacific Historical Review, Vol. 27, No. 3, pp. 281-7. Berkeley and Los Angeles.

Comment [on The Hypothesis of Slow Cyclical Variation of Creativity, by Samuel Stewart West]. The American Journal of Sociology, Vol. 68, No. 2, pp. 149-51. Chicago.

Style and Civilizations. Cornell University Press, Ithaca. [viii], $191 \mathrm{pp}$ 


\section{8}

Gray's Epicyclical Evolution. American Anthropologist, Vol. 60, No. 1, pp. 31-38. Menasha.

The Personality of Anthropology. Kroeber Anthropological Society Papers, No. 19, pp. 1-5. Berkeley.

1959

Comments on the Gray's Four Hundred Year Cycle in Human Ability. Comparative Studies in Society and History, Vol. 1, No. 3, pp. 230-41. The Hague.

The History of the Personality of Anthropology. American Anthropologist, Vol. 61, No. 3, pp. 398-404. Menasha.

Obituary: Philip Haxall Bagby. American Anthropologist, Vol. 61, No. 6, p. 1075. Menasha.

Potsherd Chronology of Sites near Zuñi Pueblo. The Archaeologist at Work; a Source Book in Archaeological Method and Interpretation, edited by Robert
F. Heizer, pp. 383-93. Harper \& Brothers, New York. [Reprint of Zuñi Potsherds, 1916, pp. 7-21.]

\section{0}

Evolution, History and Culture. Evolution after Darwin, Vol. II, The Evolution of Man; Man, Culture and Society, edited by Sol Tax, pp. 1-16. University of Chicago Press, Chicago.

Review: Indian Art of the Americas. Donald Collier. (Catalogue of an Exhibition at Chicago Natural History Museum, 1959.) American Antiquity, Vol. 25, No. 4, pp. 615-6. Salt Lake City.

1962

The Rancho La Brea Skull. (With Prefatory Remarks by Robert F. Heizer.) American Antiquity, Vol. 27, No. 3, pp. 416-7. Salt Lake City. 